\title{
Calcium - Magnesium imbalance implicated in benign prostatic hyperplasia and restoration by a phytotherapeutic drug - Croton membranaceus Müll.Arg
}

George Awuku Asare ${ }^{1,7^{*}}$, Robert A. Ngala ${ }^{2}$, Daniel Afriyie ${ }^{3}$, Samuel Adjei ${ }^{4}$, Adriana Nyarko ${ }^{2}$, Yvonne Anang-Quartey $^{1}$, Bernice Asiedu', Derek Doku', Brodrick Y. Amoah ${ }^{1}$, Kennedy Bentum ${ }^{1}$, Iddi Musah ${ }^{5}$ and Kensese Mossanda ${ }^{6}$

\begin{abstract}
Background: Calcium (Ca)- magnesium (Mg) imbalance is implicated in prostate cancer. Ca/Mg ratio increases or decreases with proliferation or apoptosis, respectively. The study examined whether this $\mathrm{Ca} / \mathrm{Mg}$ imbalance exists in $\mathrm{BPH}$ patients and the effect of a phytotherapeutic drug on the $\mathrm{Ca} / \mathrm{Mg}$ ratio.

Methods: Thirty (30) BPH patients who used the ethanolic root extract of Croton membranaceus (60 mg/day) for 3 months were examined for serum Ca, Mg, phosphate, parathyroid hormone (PTH), vitamin D, prostate specific antigen (PSA) levels and renal function tests (RFT) before (BT) and after treatment (AT) alongside thirty (30) controls. Twenty (20) trace element including Mg and Ca were determined in the drug by neutron activation analysis (NAA).

Results: RFT, PTH and vitamin D for BT, AT and controls (C) were normal. Mean PSA was $1.0 \pm 0.64$ (C), $27.9 \pm 19.0$ (BT) and $16.2 \pm 11.8 \mathrm{ng} / \mathrm{mL}(\mathrm{AT})(p=0.002)$. Mg, Ca/Mg ratio BT, AT and control were significantly different $(p=0$. 0001, respectively). After treatment, $\mathrm{Mg}$ and $\mathrm{Ca} / \mathrm{Mg}$ ratio were not different from controls. The prevalence of $\mathrm{Ca} / \mathrm{Mg}$ imbalance was 80\% (BT), 13.3\% (AT) and 3.3\% (control group).
\end{abstract}

Conclusion: $\mathrm{Ca} / \mathrm{Mg}$ ratio imbalance is associated with $\mathrm{BPH}$. This has previously not been demonstrated. The imbalance was significantly corrected after treatment with the phytotherapeutic drug.

Keywords: Calcium, Magnesium, Benign prostatic hyperplasia, Croton membranaceus

\section{Background}

Epidemiological studies of a cohort in Taiwan associated drinking water $\mathrm{Ca}$ and $\mathrm{Mg}$ levels, to prostate cancer (PCa) deaths. The authors concluded that Mg from the drinking water or other dietary sources was protective against prostate cancer [1]. Major trace elements such as cadmium $(\mathrm{Cd})$, nickel $(\mathrm{Ni})$, zinc $(\mathrm{Zn})$, copper $(\mathrm{Cu})$, iron $(\mathrm{Fe})$, magnesium $(\mathrm{Mg})$ and calcium $(\mathrm{Ca})$ have previously been identified in benign and malignant prostate samples. The concentrations of $\mathrm{Ca}$ and $\mathrm{Mg}$ have been found

\footnotetext{
* Correspondence: gasare@chs.edu.gh

'University of Ghana School of Biomedical and Allied Health Sciences (SBAHS), Korle Bu, Ghana

${ }^{7}$ Chemical Pathology Unit, Department of Medical Laboratory Sciences, School of Biomedical and Allied Health Sciences, College of Health Sciences, University of Ghana, P.O. Box KB 143, Korle-bu, Accra, Ghana

Full list of author information is available at the end of the article
}

to be significantly higher in the malignant prostate compared to the benign among other metals [2]. X-ray microanalysis on freeze-dried cryosections have been used to demonstrate that $\mathrm{Ca}$ in secretory vessels is several folds higher than $\mathrm{Mg}$ or $\mathrm{Zn}$, buttressing the fact that $\mathrm{Ca}$ is the major prostate acinar cell cation [3]. Furthermore, within the cytoplasm a positive correlation between $\mathrm{Ca}$ and $\mathrm{Mg}$ as well as $\mathrm{Ca}$ and $\mathrm{Zn}$ in hyperplastic and normal glands has been demonstrated. Additionally, increasing intranuclei $\mathrm{Ca}$ with advancing age has been observed and is believed to have pathologic significance in prostate growth disorders [3]. At the cellular level studies strongly suggest the presence of $\mathrm{Ca}$ and $\mathrm{Mg}$ imbalance in PCa cases [4].

Elevated extracellular calcium is thought to prevent apoptosis via the Ca-sensing receptor [5]. Serum $\mathrm{Mg}$ 
levels of PCa patients when examined revealed a significantly high $\mathrm{Ca} / \mathrm{Mg}$ ratio. This was accounted for by an equally significant lower $\mathrm{Mg}$ level. The odds indicated that an elevated $\mathrm{Ca} / \mathrm{Mg}$ ratio was associated with the increased risk of high-grade $\mathrm{PCa}$. On the other hand, elevated $\mathrm{Mg}$ was significantly associated with a lower risk. However, serum levels of $\mathrm{Ca}$ alone were not associated with $\mathrm{PCa}$ and $\mathrm{Ca} / \mathrm{Mg}$ levels were also not associated with $\mathrm{BPH}$ [6]. The $\mathrm{Ca} / \mathrm{Mg}$ ratio has been implicated in proliferation of prostate cancer cells compared to controls [4]. $\mathrm{Ca}^{2+}$ signaling is therefore important in regulating other physiological functions such as cell proliferation and differentiation in conjunction with $\mathrm{Mg}$ [6-10].

$\mathrm{Mg}$ upon mitotic stimulation can initiate cell proliferation by activating $\mathrm{Mg}^{2+}$ influx and increasing intracellular $\mathrm{Mg}^{2+}[11,12]$. Because both $\mathrm{Ca}$ and $\mathrm{Mg}$ are able to operate in a similar mechanism the efflux of both extracellular metals needs tight control. An increase in cytosolic $\mathrm{Ca}^{2+}$ for example regulates apoptosis $[13,14]$. At the extracellular level, an increase in $\mathrm{Ca}^{2+}$ or a decrease in extracellular $\mathrm{Mg}^{2+}$ further increased $\mathrm{Ca}^{2+}$ influx. The efflux control of $\mathrm{Ca}$ and $\mathrm{Mg}$ is regulated by a melastatin-like transient receptor potential (TRPM). These are a diverse group of voltage-independent $\mathrm{Ca}^{2+}$-permeable cation channels present in mammalian cells. TRPM6/7 gene mutations have been demonstrated in hereditary hypomagnesaemia caused by $\mathrm{Mg}^{2+}$ reabsorption impairment [15]. Additionally, other studies have shown $\mathrm{Mg}^{2+}$ entry preference over $\mathrm{Ca}^{2+}$ However, in the absence of $\mathrm{Mg}^{2+}$, the channels are able to conduct $\mathrm{Ca}^{2+}$ currents. Therefore, an increase in extracellular $\mathrm{Ca}^{2+}$ or a decrease in extracellular $\mathrm{Mg}^{2+}$ increases $\mathrm{Ca}^{2+}$ influx. Additionally, the subsequent increase in the $\mathrm{Ca}^{2+} / \mathrm{Mg}^{2+}$ ratio and TRPM7 expression has been demonstrated in age-matched prostate cancer patients. Therefore, an increase in the serum $\mathrm{Ca}^{2+} / \mathrm{Mg}^{2+}$ ratio will increase $\mathrm{Ca}^{2+}$ entry by the activation of TRPM7 channels, which eventually leads to increased cell proliferation and cancer formation [4].

Current literature has provided evidence of the $\mathrm{Ca} / \mathrm{Mg}$ hemostasis and its involvement in cell proliferation as well as prostate cancer development. The tight regulation of this channel has also been attributed to the TRMP7 gene and the $\mathrm{Ca} / \mathrm{Mg}$ ratio has also been demonstrated in clinical studies of PCa patients. However, what remains largely unknown is the presence or absence of this ratio imbalance in $\mathrm{BPH}$ patients. This study therefore sought to examine retrospectively, the $\mathrm{Ca} / \mathrm{Mg}$ balance in a cohort of BPH patients before and after three (3) months of treatment.

\section{Methods}

\section{Study design and site}

The study was a retrospective observational study. The folders of $30 \mathrm{BPH}$ patients under medical supervision who had opted for the use of a phytotherapeutic drug from the ethanolic root extract of Croton membranaceus capsules $(20 \mathrm{mg}$ t.i.d.) for a period of 3 months at the Ghana Police Hospital Urology Clinic were examined. Frozen archival blood samples were selected and examined based on patients who chose this form of therapy which had just been introduced between January 2013 and December 2014. The Ghana Police Hospital is one of the 11 centers in the country approved by the Ministry of Health to administer plant medicine. Thirty (30) other control subjects within the age group who were diagnosed negative for $\mathrm{BPH}$ within the study period were also used.

\section{Ethical issues}

The project was approved by the Ethics and Protocol Review Committee of the School of Biomedical and Allied Health Sciences with Ethics number SAHS-ET/ SAHS/PSM/ML/09/AA/26A/2012-2013. Furthermore, approval was sought from the Police Hospital administration. Informed consent was also sought from all participants whose information and samples were used. The study complied with the Helsinki Declaration of 1964, with revision in October 2008.

\section{Blood samples}

A previous study was undertaken by this same group of researchers that demonstrated the efficacy of Croton membranaceus for BPH [16]. The rest of the samples were achieved for this study. The ethics approval of the previous study covered the present study. Archival blood samples from that previous study were selected and examined based on patients who chose this form of drug therapy (phytotherapy). Samples of patients who reported to the Urology Department between January 2013 and December 2014 and opted for the phototherapeutic treatment were used. All blood samples for the PSA test as requested by the urologist at that time were taken between 8 am and $12 \mathrm{pm}$. Blood samples (sera) were then stored in the $-20{ }^{\circ} \mathrm{C}$ freezer. These samples were retrieved in January 2016 for the present study from the Biochemistry Laboratory freezer and analyzed for PSA, serum $\mathrm{Ca}, \mathrm{Mg}$, P, PTH, vitamin D, renal function (and albumin for calcium correction). The aforementioned assays were analyzed for single samples [control (C)] whilst test cases had analysis done for "before treatment" (BT) and "after treatment" (AT) samples.

\section{Phytotherapeutic drug trace element (TE) analysis}

Twenty (20) trace elements of the phytotherapeutic drug [arsenic (As), chloride $(\mathrm{Cl})$, cobalt $(\mathrm{Co})$, chromium $(\mathrm{Cr})$, copper $(\mathrm{Cu})$, cadmium $(\mathrm{Cd})$, mercury $(\mathrm{Hg})$, lead $(\mathrm{Pb})$, nickel $(\mathrm{Ni})$, iron $(\mathrm{Fe})$, manganese $(\mathrm{Mn})$, iodine $(\mathrm{I})$, vanadium $(\mathrm{V})$, aluminum $(\mathrm{Al})$, magnesium $(\mathrm{Mg})$, selenium 
$(\mathrm{Se})$, potassium $(\mathrm{K})$, sodium $(\mathrm{Na})$, calcium $(\mathrm{Ca})$, and zinc $(\mathrm{Zn})]$ were also examined by neutron activation analysis.

\section{Biochemical assays PSA}

Total PSA (TPSA) was performed using AccuBind total PSA ELISA kits purchased from MonoBind Inc. (California, USA) according to the manufacturer's instructions. The ELISA plate was coated with highly specific monoclonal anti-PSA antibodies. In brief, $25 \mu \mathrm{l}$ of samples together with standards were aliquoted into designated wells and incubated with $100 \mu \mathrm{l}$ antibody-HRP enzyme conjugate at room temperature for $30 \mathrm{~min}$. The plate was then washed with a wash buffer after which $100 \mu \mathrm{l}$ of 3,3',5,5' - tetramethylbenzidine (TMB)/hydrogen peroxide (substrate) was then added to react with the HRP. After 15 min incubation, the reaction was terminated by the addition of concentrated $\mathrm{H}_{2} \mathrm{SO}_{4}$. The final chromogen was read at $450 \mathrm{~nm}$ on a BioTek plate reader (VT, USA). TPSA was calculated from the calibration curve.

\section{Parathyroid hormone (PTH) and vitamin D}

PTH and vitamin D levels were estimated by ELISA techniques using Sunlong Biotech Co. Ltd. (Hangzhou, China). In brief, microtiter plates coated with PTH and vitamin D antibodies were used. PTH and vitamin D from the blood samples reacted with the antibodies immobilized on the plate and the immunogen was further developed using a second antibody-horseradish peroxidase conjugate. The final chromogen was read at $450 \mathrm{~nm}$.

\section{Calcium/Magnesium/Phosphorous determination}

Serum concentration of $\mathrm{Ca}, \mathrm{Mg}$, phosphorous (P), urea, creatinine, sodium, potassium and albumin were determined by standard analytic methods on the Mindray BS 300 Chemistry analyzer (New York, USA) using commercial kits from Elitech (France). All assays were performed with standards and controls.

\section{Trace element analysis of phytotherapeutic drug}

It has been suggested that $\mathrm{Mg}$ and other trace elements (TE) supplementation may play a role in shrinking an enlarged prostate. To this end, TE analysis was performed to ascertain whether the phytotherapeutic drug could possible play the role of a TE supplement. In brief, TE were determined by neutron activation analysis (NAA) at the Ghana Atomic Energy Commission. Samples of de-capsulated extract (Croton membranaceus) alongside international standards and controls were irradiated in the Ghana Research Reactor - 1 (GHARR-1) operating at $15 \mathrm{KW}$ and a thermal flux of $5 \times 1011$ n.cm -2. S-1. Samples were irradiated for 5 min followed by $10 \mathrm{~min}$ of counting. The radioactivity measurement of induced radionuclide was performed by a PC interfaced with the $\gamma$-ray spectrometric equipment. The following trace elements were analyzed: $\mathrm{As}, \mathrm{Cl}, \mathrm{Co}, \mathrm{Cr}, \mathrm{Cu}, \mathrm{Cd}$, $\mathrm{Hg}, \mathrm{Pb}, \mathrm{Ni}, \mathrm{Fe}, \mathrm{Mn}, \mathrm{I}, \mathrm{V}, \mathrm{Al}, \mathrm{Mg}$, Se, K, Na, Ca, and $\mathrm{Zn}$

\section{Statistical analysis}

IBM SPSS statistics for Windows, Version 21.0 (Armonk, NY: IBM Corporation) and Microsoft Excel 2013 were used for the statistical analysis. Data was presented as mean \pm standard deviation. Statistical analysis between groups was determined by student's t-test. Categorical variables were expressed as proportion. Correlation analysis was performed with Pearson correlation test. The level of significance was 0.050 .

\section{Results}

Mean age for the control group was $56.14 \pm 6.77$ years and that of the BPH group was $66.13 \pm 11.04$ years. Mean PSA levels of controls, before treatment (BT) and after treatment cases (AT) were $1.0 \pm 0.64,27.9 \pm 19.0$ and $16.2 \pm$ $11.8 \mathrm{ng} / \mathrm{mL}$, respectively. There was a significant difference before and after treatment $(P=0.002)$ (Table 1$)$.

Serum Mg concentration was lower for BPH cases $(\mathrm{BT}=0.64 \pm 0.18, \mathrm{AT}=0.77 \pm 0.16 \mathrm{mmol} / \mathrm{L})$, but higher for the control group $(0.8 \pm 0.1 \mathrm{mmol} / \mathrm{L})$. Control group and BT group $\mathrm{Mg}$ differences were significant $(p=$ $0.0001)$. Similarly, Mg BT and AT were different ( $p=$ $0.0031)$. Mg concentration differences were no more significantly different after treatment compared to the control or BT (Table 1).

Serum Ca levels did not demonstrate significant differences between the three groups. However, slight increases were observed in the test group before treatment. Although the levels were marginal, levels dropped to that of the control after treatment $(\mathrm{C}=2.3 \pm 0.24, \mathrm{AT}=2.29 \pm$ $0.44 \mathrm{mmol} / \mathrm{L}$ ) (Table 1). Similarly, changes in P showed a slight increasing trend from C, BT to AT. However, increases were not significant (Table 1).

The $\mathrm{Ca} / \mathrm{Mg}$ ratios were as follows: $\mathrm{C}=2.87 \pm 0.48$; $\mathrm{BT}$ $=3.81 \pm 1.12 ; \quad \mathrm{AT}=2.96 \pm 0.68$. Significant differences were observed between the C and BT $(p=0.0001)$ and $\mathrm{BT}$ and AT (0.0001). However, the ratio after treatment and that of the control group no longer showed significant differences (Table 1). Parathyroid hormone and vitamin $\mathrm{D}$ as well as the renal function test did not show any statistical difference (Tables 2 and 3, respectively).

There was a positive correlation between $\mathrm{Ca}$ and $\mathrm{Mg}$ before treatment $(r=0.391 ; p=.033)$. However, this correlation did not exist after treatment with levels similar to the control group. Similarly, there was a positive correlation between $\mathrm{Mg}$ and $\mathrm{P}$ before treatment $(r=0.398$; $p=.029$ ). Correlation no longer existed after treatment with levels similar to the control group (Table 4).

Between $\mathrm{Ca}$ and $\mathrm{P}$ a positive correlation existed in the disease state (Table 4). A phosphate $\mathrm{Ca} / \mathrm{Mg}$ correlation 
Table 1 Table showing PSA differences as well as Ca, Mg and PO4 levels of the control and BPH group

\begin{tabular}{lcccc}
\hline & Mean \pm SD Control group & Mean \pm SD Treatment group (Before -BT) & Mean \pm SD Treatment group (After - AT) & $p$-value \\
\hline PSA ng/mL & $1.0 \pm 0.64$ & $27.9 \pm 19.0^{\mathrm{b}}$ & $16.2 \pm 11.8^{\mathrm{b}}$ & 0.002 \\
$\mathrm{Mg} \mathrm{mmol} / \mathrm{L}$ & $0.8 \pm 0.1^{\mathrm{a}}$ & $0.64 \pm 0.18^{\mathrm{a}, \mathrm{b}}$ & $0.77 \pm 0.16^{\mathrm{b}}$ & $0.0001^{\mathrm{a}} / 0.0031^{\mathrm{b}}$ \\
$\mathrm{Ca} \mathrm{mmol} / \mathrm{L}$ & $2.30 \pm 0.24$ & $2.44 \pm 0.85$ & $2.29 \pm 0.44$ & $\mathrm{NS}$ \\
$\mathrm{PO}_{4} \mathrm{mmol} / \mathrm{L}$ & $1.4 \pm 0.3$ & $1.53 \pm 0.35$ & $1.63 \pm 0.32$ & $\mathrm{NS}$ \\
$\mathrm{Ca} / \mathrm{Mg}$ & $2.87 \pm 0.48^{\mathrm{a}}$ & $3.81 \pm 1.12^{\mathrm{a}, \mathrm{b}}$ & $2.96 \pm 0.68^{\mathrm{b}}$ & $0.0001^{\mathrm{a}} / 0.0001^{\mathrm{b}}$ \\
\hline
\end{tabular}

${ }^{\mathrm{a}}$ Indicates comparison between control and test groups; whist ${ }^{\mathrm{b}}$ indicates comparison between Before Treatment levels and After Treatment. NS not significant $(n=30)$

was highly significant and inversely correlated in the control group $(r=-0.884)$. This correlation existed moderately in the test groups (Table 4). Calcium $\mathrm{Ca} / \mathrm{Mg}$ ratio showed a strong positive correlation in the control group $(r=$ $0.700 ; p<.001)$. This correlation also existed in the disease groups to a moderate extent (Table 4). The magnesium $\mathrm{Ca} / \mathrm{Mg}$ ratio showed a strong inverse correlation in the control group $(r=-0.755 ; p<.001)$. However, the correlation was moderate in the disease group (Table 4). No correlation was observed between TPSA and $\mathrm{Ca} / \mathrm{Mg}$ ratio.

The prevalence of hypomagnesemia in $\mathrm{BPH}$ patients was $86.7 \%$ in tandem with a hypercalcemia of $36.7 \%$. Both levels were approximately 5 and 4 times, respectively, that of the control group. After treatment $\mathrm{Mg}$-Ca levels were almost that of the control group (Table 5). The prevalence of the $\mathrm{Ca} / \mathrm{Mg}$ imbalance using the upper limit of the control group [2.87 (2.39-3.35)] was $80 \%$ before treatment (BT). This was reduced to $13.3 \%$ after treatment (AT). The control group prevalence was 3.3\% (Table 5).

Out of the 30 cases only 18 had their prostate volumes on record. There was no correlation between the $\mathrm{Ca} / \mathrm{Mg}$ ratio and the prostate volume (Table 6).

To ascertain whether the $\mathrm{Ca} / \mathrm{Mg}$ ratio that was apparently corrected after treatment could be related to TE in the phytotherapeutic drug, TE analysis was conducted. From Table 7, Ca was of the highest concentration (58446 $\mathrm{mg} / \mathrm{kg}$ dry wt.); this was followed by $\mathrm{K}$ (7452 $\mathrm{mg} / \mathrm{Kg}$ dry wt.). The third highest was $\mathrm{Mg}$ (3239 mg/kg dry wt.). Traditional antioxidants that have been suggested to aid prostate treatment were very low $(\mathrm{Zn}=2.992$ and $\mathrm{Se}=0.16 \mathrm{mg} / \mathrm{Kg}$ dry wt.). Other toxic ultra-trace elements such as $\mathrm{Hg}$, As and $\mathrm{Pb}$ were of negligible quantities (Table 7).

\section{Discussion}

Minerals are naturally occurring elements found in the earth with a characteristic crystalline structure and chemical composition. Dietary minerals are inorganic nutrients and are usually required in small amounts of 1-2500 $\mathrm{mg}$ per day [17]. The inorganic nature of these micro-nutrients differentiates them from the other micro-molecules that are organic such as vitamins [18]. Traditionally, minerals are grouped into two categories; macro (major) - and micro - (trace) elements. A third category is the ultra-trace element [19]. Whereas the macro - and micro - elements are required in amounts $>100 \mathrm{mg} /$ day and $<20 \mathrm{mg} /$ day, respectively, ultra-trace elements are required in the region of $1 \mathrm{mg} /$ day. Arsenic, bromine, boron, chromium, cadmium, fluorine, lead, lithium, molybdenum, nickel, selenium, silicon, tin and vanadium fit into this category [19].

The importance of trace elements to health cannot be under-estimated even though they are required in minute quantities. At least 17 known essential elements and many others are needed for good health and inadequate amounts of trace elements such as sodium, potassium, magnesium and calcium have a link to the development of diseases [20]. Trace metal concentrations including $\mathrm{Cd}, \mathrm{Ni}, \mathrm{Zn}, \mathrm{Cu}, \mathrm{Fe}, \mathrm{Mg}$, and $\mathrm{Ca}$ in both malignant and benign prostate samples have been determined [2].

Imbalance in trace elements such as $\mathrm{P}, \mathrm{Ca}, \mathrm{Mg}$ that are essential to normal human homeostasis, results in a number of clinical complications including prostate cancer. Suggested processes implicated in the progression of prostate disorders are from oxidative stress, to cellular senescence [21, 22]. Mineral metabolism which includes $\mathrm{Ca}, \mathrm{Mg}$ and $\mathrm{P}$ occurs through three main target organs: the bone, intestine and kidney. The homeostatic control of these minerals is primarily facilitated by the parathyroid hormone and vitamin D.. However, there is still a gap in our understanding regarding the relationship between trace element functions and initiation as well as

Table 2 Parathyroid hormone (PTH) and Vitamin D levels of the control and BPH group

\begin{tabular}{lcccc}
\hline Parameter & Mean \pm SD Control group & Mean \pm SD Treatment group (Before - BT) & Mean \pm SD Treatment group (After - AT) & $P$-value \\
\hline PTH $(\mathrm{pg} / \mathrm{mL})$ & $45.26 \pm 19.72$ & $50.68 \pm 18.87$ & $49.36 \pm 17.61$ & NS \\
Vitamin D $(\mathrm{ng} / \mathrm{mL})$ & $30.60 \pm 18.98$ & $28.55 \pm 8.70$ & $32.06 \pm 12.76$ & $\mathrm{NS}$ \\
\hline
\end{tabular}

$n=30$; NS not significant 
Table 3 Renal function tests of the control and BPH group

\begin{tabular}{lcccc}
\hline Parameter & Mean \pm SD Control group & Mean \pm SD Treatment group (Before- BT) & Mean \pm SD Treatment group (After - AT) & $P$-value \\
\hline Sodium $(\mathrm{mmol} / \mathrm{l})$ & $140.6 \pm 3.5$ & $142.8 \pm 6.6$ & $142.2 \pm 6.6$ & $4.3 \pm 0.6$ \\
Potassium $(\mathrm{mmol} / \mathrm{l})$ & $4.2 \pm 0.5$ & $4.3 \pm 0.6$ & $4.4 \pm 1.3$ & $\mathrm{NS}$ \\
Urea $(\mathrm{mmol} / \mathrm{l})$ & $4.0 \pm 2.3$ & $4.3 \pm 1.4$ & $106.0 \pm 26.2$ & $\mathrm{NS}$ \\
Creatinine $(\mu \mathrm{mol} / \mathrm{l})$ & $89.3 \pm 23.4$ & $105.9 \pm 26.5$ & $\mathrm{NS}$ \\
\hline
\end{tabular}

$N=30 ; N S$ not significant

progression and inhibition of the carcinogenic process in the prostatic gland [23, 24].

In this study $\mathrm{Mg}$ levels were found to be significantly lower in patients with $\mathrm{BPH}$ compared to the control group. $\mathrm{Mg}$ has an effect on a variety of cell membranes through a process involving $\mathrm{Ca}$ channels and ion transport mechanisms. $\mathrm{Mg}$ is therefore responsible for the maintenance of the trans-membrane gradients of sodium and potassium [25].

On the other hand $\mathrm{Ca}$ was significantly higher in patients with BPH compared to the controls. Serum Ca was shown not to be associated with the risk of prostate cancer [26]. Contrary to this, a weak negative association has been shown between serum $\mathrm{Ca}$ and the incidence of fatal prostate cancer in Swedish men [27]. Furthermore, the association between serum $\mathrm{Ca}$ levels and aggressive lesions or fatal prostate cancer has been observed in some studies [28]. It has been previously hypothesized that high serum $\mathrm{Ca}$ or $\mathrm{PTH}$ increase, is a risk factor for fatal prostate cancer [29]. However, Ca levels in BPH patients have not been previously demonstrated to be associated with the development of this condition.

This study demonstrated a moderate positive association between $\mathrm{Ca}$ and $\mathrm{Mg}$ as well as $\mathrm{Mg}$ and $\mathrm{P}$ in the disease state. The association disappeared after treatment and was similar to the status of the controls. Indeed $\mathrm{Ca}$ and $\mathrm{Mg}$ are both reabsorbed at the loop of Henle. The correlation was perhaps an attempt to create the necessary balance by increasing $\mathrm{Mg}$ reabsorption. Although $\mathrm{Ca}$ may be reabsorbed alongside $\mathrm{Mg}$, both may not be to the same extent and perhaps Ca reabsorption is truncated when $\mathrm{Mg}$ is adequately reabsorbed. It has been shown that $\mathrm{Ca}$ reabsorption is not altered in $\mathrm{Mg}$ deficiency; however, elevations of extracellular $\mathrm{Mg}$ results in a specific inhibition of Ca reabsorption within the loop of Henle [30]. This positive correlation disappeared after treatment when the $\mathrm{Ca} / \mathrm{Mg}$ ratio had normalized.

The $\mathrm{P}$ and $\mathrm{Mg}$ positive correlation may be due to $\mathrm{P}$ co-absorption with $\mathrm{Mg}$ as a compensatory mechanism. The P reabsorption may not be PTH controlled but a reduction in the amount of titrable $\mathrm{P}$ at the distal convoluted tubules. It is postulated that an abnormal homeostasis occurs. It has been demonstrated that in parathyroidectomized rats, $\mathrm{Mg}$ depletion was equally associated with P depletion. However, one study has suggested that the overall control of renal $\mathrm{Mg}$ reabsorption occurs within the loop of Henle and that the proximal tubule reabsorbs a constant fraction of the filtered load despite variations in body $\mathrm{Mg}$ status [30]. In that study, proximal $\mathrm{Mg}$ reabsorption remained unchanged at 15\% of the filtered load and was unaffected by Mg deficiency or acute $\mathrm{Mg}$ repletion. However, distal tubular Mg reabsorption was limited during depletion and increased to a similar extent in control and deficient rats with enhanced Mg delivery [30]. The mechanism of P reabsorption under such circumstances of $\mathrm{Mg}$ reabsorption is not clearly understood.

Hypomagesemia has been reported in a number of disease conditions diarrhea, vomiting and gastrointestinal

Table 4 Pearson's Correlation analysis

\begin{tabular}{llllll}
\hline \multicolumn{2}{l}{ Correlation Parameters } & \multicolumn{2}{l}{ Control Group } & BPH Group Before Treatment & BPH Group After Treatment \\
\hline Parameter A & Parameter B & & & & \\
\\
\end{tabular}

\footnotetext{
${ }^{a}$ Correlation is significant at the 0.05 level (2-tailed)
}

${ }^{\mathrm{b}}$ Correlation is significant at the 0.01 level (2-tailed) 
Table 5 Prevalence of low Mg and high Ca levels as well as the Ca/Mg ratio imbalance

\begin{tabular}{lccc}
\hline Prevalence levels of $\mathrm{Mg}$ and $\mathrm{Ca}$ & Control group & Treatment group (Before - BT) & Treatment group (After - AT) \\
\hline Prevalence of low Mg (\%) & 16.7 & 86.7 & 13.3 \\
Prevalence of high Ca (\%) & 10.0 & 36.7 & 13.0 \\
Prevalence of Ca/Mg ratio imbalance (\%) & 3.33 & 80.0 & 13.3 \\
\hline
\end{tabular}

$n=30$

fistulas. A prevalence of $11 \%$ was reported when 621 hospital patients (in the USA) were randomly selected compared to $2.5 \%$ in the control group made up of 341 hospital staff [31]. Other disease conditions such as malabsorption, diarrhea, hypertension, cognitive heart failure, coronary artery disease among others have all been reported to be associated with hypomagnesaemia [32, 33]. Hypomagnesaemia was present in $86.7 \%$ of the patients diagnosed with BPH. The control group had a hypomegnesemia prevalence of $16.7 \%$ which is comparable to a prevalence of $14.5 \%$ among 16,000 apparently normal Germans studied [34]. The prevalence for 11,000 white urban Americans (45 to 64 years) was between 2.5 and $5 \%$ depending on the lower limit used. Twice this prevalence was found in African Americans [35]. The 80\% prevalence of a high $\mathrm{Ca} / \mathrm{Mg}$ ratio was reduced to $13.3 \%$ after treatment, although this was still higher than the $3.3 \%$ prevalence found in the control group.

The phytotherapeutic drug that was administered (made of Croton membranaceus) was analyzed for its trace element content. It was noted that the extract was high in $\mathrm{Ca}$, followed by potassium and $\mathrm{Mg}$. Indeed the $\mathrm{Ca}$ level was 18 times that of $\mathrm{Mg}$; nevertheless $\mathrm{Ca}$ absorption is always tightly regulated. Although the serum $\mathrm{Mg}$ level was significantly low while the $\mathrm{Ca} / \mathrm{Mg}$ ratio was significant high before treatment, the $\mathrm{Mg}$ level significantly increased to that of the controls and the $\mathrm{Ca}$ / $\mathrm{Mg}$ ratio significantly reduced to the level of the controls after treatment.

In several studies investigating the relationship between $\mathrm{Ca}$ intake and the risk of developing aggressive or clinically relevant prostate cancers as well as the relationship between prostate disorders, PTH and vitamin D have both generated null $[26,36]$ and positive results [37]. Blood Ca levels are tightly regulated and only moderately affected by dietary intake of $\mathrm{Ca}$ and absorption rates [38]. Thus, one possible explanation for the inconsistencies across study populations is that dietary intake measures of $\mathrm{Ca}$ may not accurately reflect the blood $\mathrm{Ca}$ concentrations to which prostate tissues are exposed [6].
Whether the phytotherapeutic drug's trace element levels contributed to the correction of the $\mathrm{Ca} / \mathrm{Mg}$ imbalance in the $\mathrm{BPH}$ group is a mechanism to consider or whether the corrected imbalance is a result of some other mechanism(s), is debatable. The former is very unlikely considering the RDA for $\mathrm{Ca}$ and $\mathrm{Mg}$ and the overall $60 \mathrm{mg}$ intake of the plant extract drug which is far below the RDA. Nevertheless, the imbalance and its association with the $\mathrm{Ca}$ channels remain plausible.

$\mathrm{Ca}$ channels and the $\mathrm{Ca} / \mathrm{Mg}$ ratio is a developing area of focus. The $\mathrm{Ca} / \mathrm{Mg}$ ratio in this study was significantly raised in the $\mathrm{BPH}$ group compared to the control group. Studies have shown that inadequate $\mathrm{Mg}$ levels, relative to $\mathrm{Ca}$ levels (i.e. high $\mathrm{Ca} / \mathrm{Mg}$ ratio) are associated with greater risk of prostate disorders. Among high-grade prostate cancer cases compared to controls, serum $\mathrm{Mg}$ levels were significantly lower, while the $\mathrm{Ca} / \mathrm{Mg}$ ratio was significantly higher. An elevated $\mathrm{Ca} / \mathrm{Mg}$ ratio was therefore associated with an increased risk of high-grade prostate cancer and elevated Mg was significantly associated with a lower risk [6]. However, only one or two studies seem to have examined this phenomenon in $\mathrm{BPH}$ patients.

It has been recently demonstrated that a high $\mathrm{Ca} / \mathrm{Mg}$ ratio is pro-inflammatory and $\mathrm{Mg}$ increase reverses this imbalance through gate-keeping activities of TRPM6/7 gene in an apoptotic drive. The apoptotic mechanism of this phytotherapeutic drug made of Croton membraneus on BPH-1 cells have recently been demonstrated [39]. Therefore, the present $\mathrm{Ca} / \mathrm{Mg}$ ratio correction is still in keeping with the apoptotic mechanism established previously by [39].

The PSA levels were also reduced significantly after treatment and symptoms improved significantly by the International Prostate Symptoms Score (IPSS) assessment as published elsewhere [16]. The correlation between $\mathrm{Ca} / \mathrm{Mg}$ and PSA levels were not established, just as the correlation between prostate volume and the $\mathrm{Ca} /$ $\mathrm{Mg}$ ratio. Whether this ratio pertains to the initiation or progression of the disease remains unknown and requires further studies.

Table 6 Calcium Magnesium levels and the corresponding prostate volumes of individuals whose data could be retrieved

\begin{tabular}{lllllllllllllllllll}
\hline Patient ID & 1 & 2 & 3 & 4 & 5 & 6 & 7 & 8 & 9 & 10 & 11 & 12 & 13 & 14 & 15 & 16 & 17 & 18 \\
\hline Ca/Mg ratio & 3.11 & 4.02 & 4.09 & 3.82 & 3.41 & 3.69 & 3.41 & 4.09 & 3.48 & 3.15 & 4.04 & 3.81 & 3.60 & 5.17 & 3.08 & 3.46 & 4.33 & 5.25 \\
Prostate vol $\left(\mathrm{cm}^{-3}\right)$ & 104 & 15.2 & 44.4 & 115 & 45.8 & 13.4 & 131 & 79.8 & 137 & 47.7 & 94.5 & 30.1 & 61 & 149 & 49.9 & 198 & 150 & 105 \\
\hline
\end{tabular}


Table 7 Trace elements in Croton membranaceus

\begin{tabular}{ll}
\hline Element & Concentration in $\mathrm{mg} / \mathrm{kg}$ dry wt. \\
\hline $\mathrm{As}$ & 0.06 \\
$\mathrm{Cl}$ & 1608 \\
$\mathrm{Co}$ & 3.45 \\
$\mathrm{Cr}$ & 4.13 \\
$\mathrm{Cu}$ & $<0.003$ \\
$\mathrm{Cd}$ & $<0.002$ \\
$\mathrm{Hg}$ & $<0.001$ \\
$\mathrm{~Pb}$ & $<0.001$ \\
$\mathrm{Ni}$ & $<0.001$ \\
$\mathrm{Fe}$ & 19.041 \\
$\mathrm{Mn}$ & 0.847 \\
$\mathrm{I}$ & $<0.001$ \\
$\mathrm{~V}$ & 3.81 \\
$\mathrm{Al}$ & 1201 \\
$\mathrm{Mg}$ & 3239 \\
$\mathrm{Se}$ & 0.16 \\
$\mathrm{~K}$ & 7452 \\
$\mathrm{Na}$ & 1128 \\
$\mathrm{Ca}$ & 58446 \\
$\mathrm{Zn}$ & 2.992 \\
\hline
\end{tabular}

\section{Conclusion}

$\mathrm{Ca} / \mathrm{Mg}$ ratio imbalance is associated with $\mathrm{BPH}$ similar to observations in PCa. This has previously not been demonstrated. The imbalance was corrected after treatment. Although apoptosis is suspected to be one of the mechanisms for the action of this pytotherapeutic drug, the actual mechanism is yet to be elucidated.

\section{Abbreviations}

AT: After treatment; BPH: Benign prostatic hyperplasia; BT: Before treatment; Ca: Calcium; Mg: Magnesium; NAA: Neutron activation analysis; Pca: Prostate cancer; PSA: Prostate specific antigen; PTH: Parathyroid hormone; RFT: Renal function tests; TE: Trace element; TPSA: Total prostate specific antigen; TRPM: Melastatin-like transient receptor potential

\section{Availability of data and material}

Data and material are included in the article.

\section{Authors' contributions}

GA - conceptualized study and drafted manuscript, NRA - supervised and drafted manuscript; DA- supervised patient recruitment and review of draft; SA - performed literature search and drafted manuscript; AN - performed laboratory analysis; YA-Q - patient recruitment and sample collection; BA statistical analysis; DD - sample analysis; BYA - literature search and drafting manuscript; KB - patient recruitment: IM - Urological examination of patients, KM - conceptualization of study and manuscript writing. All authors read and approved the manuscript.

\section{Competing interests}

The authors declare that they have no competing interests.

\section{Consent for publication}

Not applicable.

\section{Ethics approval and consent to participate}

Ethics clearance was sought from the Ethics Review Committee of the School of Biomedical and Allied Health Sciences with Ethics number SAHSET/SAHS/PSM/ML/09/AA/26A/2012-2013. Furthermore, approval was sought from the Police Hospital administration. Informed consent was also sought from all participants whose information and samples were used.

\section{Publisher's Note}

Springer Nature remains neutral with regard to jurisdictional claims in published maps and institutional affiliations.

\section{Author details}

${ }^{1}$ University of Ghana School of Biomedical and Allied Health Sciences (SBAHS), Korle Bu, Ghana. ²Department of Molecular Medicine, School of Medical Sciences, Kwame Nkrumah University of Science and Technology, Kumasi, Ghana. ${ }^{3}$ Department of Pharmacy, Ghana Police Hospital, Cantonments, Accra, Ghana. ${ }^{4}$ Noguchi Memorial Institute for Medical Research (NMIMR), University of Ghana, Legon, Ghana. ${ }^{5}$ Department of Urology, Ghana Police Hospital, Cantonments, Accra, Ghana. ${ }^{6}$ Directorate of Research, Walter Sisulu University, Mthatha, South Africa. ${ }^{7}$ Chemical Pathology Unit, Department of Medical Laboratory Sciences, School of Biomedical and Allied Health Sciences, College of Health Sciences, University of Ghana, P.O. Box KB 143, Korle-bu, Accra, Ghana.

Received: 20 December 2016 Accepted: 7 March 2017

Published online: 11 March 2017

\section{References}

1. Yang CY, Chiu HF, Tsai SS, Cheng MF, Lin MC, Sung FC. Calcium and magnesium in drinking water and risk of death from prostate cancer. J Toxicol Environ Health A. 2000;60:17-26.

2. Yaman M, Atici D, Bakirdere S, Akdeniz I. Comparison of trace metal concentrations in malign and benign human prostate. J Med Chem. 2005; 48:630-4.

3. Tvedt KE, Halgunset J, Kopstad G, Haugen OA. Intracellular distribution of calcium and zinc in normal, hyperplastic, and neoplastic human prostate: $\mathrm{X}$ ray microanalysis of freeze-dried cryosections. Prostate. 1989;15:41-51.

4. Sun Y, Selvaraj S, Varma A, Derry A, Sahmoun AE, Singh BB. Increase in Serum Ca2/Mg2 Ratio Promotes Proliferation of Prostate Cancer Cells by Activating TRPM7 Channels. J Biol Chem. 2013;288:255-63.

5. Lin Kl, Chattopadhyay N, Bai M, Alvarez R, Dang CV, Baraban JM, Brown EM, Ratan RR. Elevated extracellular calcium can prevent apoptosis via the calcium-sensing receptor. Biochem Biophys Res Commun. 1998;249:325-31.

6. Dai Q, Motley SS, Smith Jr JA, Concepcion R, Barocas D, Byerly S, Fowke JH. Blood magnesium, and the interaction with calcium, on the risk of highgrade prostate cancer. PLoS One. 2011;6:e18237.

7. Whitfield JF, Boynton AL, MacManus JP, Sikorska M, Tsang BK. The regulation of cell proliferation by calcium and cyclic AMP. Mol Cell Biochem. 1979;27:155-79.

8. Berridge MJ, Brown KD, Irvine RF, Heslop JP. Phosphoinositides and cell proliferation. J. Cell Sci. 1985;(Suppl.3):187-98.

9. Roderick HL, Cook SJ. Ca2 signaling checkpoints in cancer: remodeling Ca2 for cancer cell proliferation and survival. Nat Rev Cancer. 2008:8:361-75.

10. Sahmoun AE, Singh BB. Does a higher ratio of serum calcium to magnesium increase the risk for postmenopausal breast cancer? Med Hypotheses. 2010;75:315-8.

11. Wolf FI, Fasanella S, Tedesco B, Torsello A, Sgambato A, Faraglia B, Palozza P, Boninsegna A, Cittadini A. Regulation of magnesium content during proliferation of mammary epithelial cells (HC-11). Front Biosci. 2004;9:2056-62.

12. Rubin $\mathrm{H}$. Central roles of $\mathrm{Mg} 2$ and $\mathrm{Mg}$ ATP in the regulation of protein synthesis and cell proliferation: significance for neoplastic transformation. Adv Cancer Res. 2005;93:1-58.

13. Hajno'czky G, Davies E, Madesh M. Calcium signaling and apoptosis. Biochem Biophys Res Commun. 2003;304:445-54.

14. Rizzuto R, Pinton P, Ferrari D, Chami M, Szabadkai G, Magalhães PJ, DiVirgilio F, Pozzan T. Calcium and apoptosis: facts and hypotheses. Oncogene. 2003;22:8619-27.

15. Chubanov V, Waldegger S, Mederos Y, Schnitzler M, Vitzthum H, Sassen MC, Seyberth HW, Konrad M, Gudermann T. Disruption of TRPM6/TRPM7 complex formation by a mutation in the TRPM6 gene causes 
hypomagnesemia with secondary hypocalcemia. Proc Natl Acad Sci U S A. 2004;101:2894-9.

16. Asare GA, Afriyie D, Ngala RA, Annan Y, Appiah AA, Musah I, Adjei S, Bamfo KB, Sule SD, Gyan BA, Ahin P, Edoh DA. Shrinkage of prostate and improved quality of life: management of BPH patients with croton membranaceus ethanolic root extract. Evid Based Complement Alternat Med. 2015:10. Article ID 365205.

17. Soetan $\mathrm{KO}$, Olaiya $\mathrm{CO}$, Oyewole OE. The importance of mineral elements for humans, domestic animals and plants: a review. Afr J Food Sci. 2010;4:200-22.

18. Blake JS, Munoz KD, Volpe S. Nutrition: from science to you. 3rd ed. San Francisco: Pearson Benjamin Cummings; 2013.

19. Nielsen FH. Ultratrace elements of possible importance for human health: an update. Prog Clin Biol Res. 1993;380:355-76.

20. Sánchez-Benito JL, Sánchez-Soriano E, Ginart SJ. Unbalanced intake of fats and minerals associated with risk hypertension by young cyclists. Nutr Hosp. 2007:22:552-9.

21. Begley L, Monteleon C, Shah RB, Macdonald JW, Macoska JA. CXCL12 overexpression and secretion by aging fibroblasts enhance human prostate epithelial proliferation in vitro. Aging Cell. 2005;4:291-8.

22. Bethel CR, Chaudhary J, Anway MD, Brown TR. Gene expression changes are age-dependent and lobe-specific in the brown Norway rat model of prostatic hyperplasia. Prostate. 2009:69:838-50.

23. Guntupalli JNR, Padala S, Gummuluri AVRM, Muktineni RK, Byreddy SR, Sreerama L, Kedarisetti PC, Angalakuduru DP, Satti BR, Venkatathri V, Pullela VBRL, Gavarasana S. Trace elemental analysis of normal, benign hypertrophic and cancerous tissues of the prostate gland using the particleinduced X-ray emission technique. Eur J Cancer Prev. 2007;16:108-15.

24. Banas A, Kwiatek WM, Banas K, Gajda M, Pawlick B, Cichocki T. Correlation of concentrations of selected trace elements with Gleason grade of prostate tissues. J Biol Inorg Chem. 2010;15:1147-55.

25. Bara M, Guiet-Bara A, Durlach J. Regulation of sodium and potassium pathways by magnesium in cell membranes. Magnes Res. 1993;6:167-77.

26. Halthur C, Johansson AL, Almquist M, Malm J, Grönberg H, Manjer J, Dickman PW. Serum calcium and the risk of prostate cancer. Cancer Causes Control. 2009;20:1205-14

27. Van Hemelrijck M, Wigertz A, Sandin F, Garmo H, Hellström K, Fransson P, Widmark A, Lambe M, Adolfsson J, Varenhorst E, Johansson J-E, Stattin P. Cohort profile: the national prostate cancer register of Sweden and prostate cancer data base Sweden 2.0. Int J Epidemiol. 2013;42:956-67.

28. Skinner HG, Schwartz GG. Serum calcium and incident and fatal prostate cancer in the National Health and Nutrition Examination Survey. Cancer Epidemiol Biomarkers Prev. 2008;17:2302-5.

29. Skinner HG, Schwartz GG. The relation of serum parathyroid hormone and serum calcium to serum levels of prostate-specific antigen: a populationbased study. Cancer Epidemiol Biomarkers Prev. 2009;18:2869-73.

30. Carney SL, Wong NL, Quamme GA, Dirks JH. Effect of magnesium deficiency on renal magnesium and calcium transport in the rat. J Clin Invest. 1980;65: 180-8.

31. Wong ET, Rude RK, Singer FR, Shaw Jr ST. A high prevalence of hypomagnesemia and hypermagnesemia in hospitalized patients. Am J Clin Pathol. 1983;79:348-53.

32. Topf JM, Murray PT. Hypomagnesemia and hypermagnesemia. Rev Endocr Metab Disord. 2003;4:195-206.

33. Dacey MJ. Hypomagnesemic disorders. Crit Care Clin. 2001;17:155-73.

34. Schimatschek HF, Rempis R. Prevalence of hypomagnesemia in an unselected German population of 16,000 individuals. Magnes Res. 2001;14: 283-90.

35. Ma J, Folsom AR, Melnick SL, Eckfeldt JH, Sharrett AR, Nabulsi AA, Hutchinson RG, Metcalf PA. Associations of serum and dietary magnesium with cardiovascular disease, hypertension, diabetes, insulin, and carotid arterial wall thickness: the ARIC study. Atherosclerosis Risk in Communities Study. J Clin Epidemiol. 1995;48:927-40.

36. Chan JM, Stampfer MJ, Ma J, Gann PH, Gaziano JM, Giovannucci EL. Dairy products, calcium, and prostate cancer risk in the Physicians' Health Study1,2,3. Am J Clin Nutr. 2001;74:549-54.

37. Tseng M, Breslow RA, Graubard Bl, Ziegler RG. Dairy, calcium, and vitamin D intakes and prostate cancer risk in the National Health and Nutrition Examination Epidemiologic Follow-up Study cohort. Am J Clin Nutr. 2005; 81:1147-54.
38. Iseri LT, French JH. Magnesium: nature's physiologic calcium blocker. Am Heart J. 1984;108:188-93.

39. Afriyie DK, Asare GA, Bugyei K, Lin J, Peng J, Hong Z. Mitochondriadependent apoptogenic activity of aqueous root extract of Croton membranaceus against human BPH-1 cells. Gen Mol Res. 2015;14:149-62.

\section{Submit your next manuscript to BioMed Central and we will help you at every step:}

- We accept pre-submission inquiries

- Our selector tool helps you to find the most relevant journal

- We provide round the clock customer support

- Convenient online submission

- Thorough peer review

- Inclusion in PubMed and all major indexing services

- Maximum visibility for your research

Submit your manuscript at www.biomedcentral.com/submit
Biomed Central 